\title{
The 2011 Welsh General Election: an analysis of the latest staging post in the maturing of Welsh Politics
}

\author{
By Democratic Audit
}

The May 2011 Welsh General Election represented an important staging post in the development of a mature democracy as it followed immediately from the referendum result which gave the Assembly full-primary legislative powers. Here Michael Cole draws on an article written with Professor Laura McAllister, recently published by Parliamentary Affairs, to discuss the campaign, its results and the operation of the electoral system.

\section{Policy themes and campaign debates}

The responsibilities of Welsh government pushed the agenda onto topics like health, transport, economic development and education. This focus also reflected the centre-left orientation of Welsh politics, with a much greater belief in universalism and the worth of state provision. The campaign was influenced by fall-out from the referendum. Specifically, Plaid expected an electoral bonus from the 'yes' result to match that of the first Assembly election, a confidence that perhaps explained their lacklustre and disjointed campaign.

The campaign was (of course) affected by ongoing devolution dynamics. Specifically, Plaid sought the transfer of a range of significant functions to the Assembly, for example criminal justice, broadcasting, energy and natural resources, and the railways. Alternatively, Labour suggested no specific proposals to move additional responsibilities to Wales, while the Conservatives and Liberal Democrats advanced more modest agendas, for example shifting policing and justice and large-scale energy projects (Liberal Democrats) and smaller-energy schemes and Network Rail (Conservatives).

\section{Results}

Welsh Labour was the clear winner, returning $30 \mathrm{AMs}$, enough to enable the formation of a single-party government. Labour gained four constituencies (Blaenau Gwent, Cardiff North, Cardiff Central and Llanelli), while retaining its two list AMs. The Welsh Conservatives also made a good showing, gaining two constituencies (Aberconwy and Montgomeryshire) and two extra list seats, although party leader (Nick Bourne) and rising star (Jonathan Morgan) were both defeated. Overall, the Conservatives made a net gain of two seats. For Plaid, this was their worst Welsh General Election result, losing two constituencies (Aberconwy and Llanelli) and two list seats. An immediate inquest and resignation of party leader, leuan Wyn Jones, followed. The Liberal Democrats also suffered their worst result; however they only suffered a net decline of one AM. The loss of two constituencies (Cardiff Central and Montgomeryshire) and a list seat were partly counteracted by list gains in South Wales Central and Mid and West Wales.

Table 1: Welsh General Election Results, 2007 and 2011 


\begin{tabular}{|l|c|c|c|c|c|c|c|c|}
\hline & \multicolumn{2}{l}{ Labour } & \multicolumn{2}{l|}{ Conservative } & \multicolumn{2}{l|}{ Plaid Cymru } & \multicolumn{2}{l|}{$\begin{array}{l}\text { Liberal } \\
\text { Democrats }\end{array}$} \\
\hline & Vote\% & Seats & Vote\% & Seats & Vote\% & Seats & Vote\% & Seats \\
\hline $\begin{array}{l}\text { Constituency } \\
\mathbf{2 0 0 7}\end{array}$ & 32.2 & 24 & 22.4 & 5 & 22.4 & 7 & 14.8 & 3 \\
\hline $\begin{array}{l}\text { Regional List } \\
\mathbf{2 0 0 7}\end{array}$ & 29.6 & 2 & 21.4 & 7 & 21.0 & 8 & 11.7 & 3 \\
\hline Total 2007 & & 26 & & 12 & & 15 & & 6 \\
\hline $\begin{array}{l}\text { Constituency } \\
\mathbf{2 0 1 1}\end{array}$ & 42.3 & 28 & 25.0 & 6 & 19.3 & 5 & 10.6 & 1 \\
\hline $\begin{array}{l}\text { Regional List } \\
\mathbf{2 0 1 1}\end{array}$ & 36.9 & 2 & 22.5 & 8 & 17.9 & 6 & 8.0 & 4 \\
\hline Total 2011 & & 30 & & 14 & & 11 & & 5 \\
\hline
\end{tabular}

\section{The 'Second-Order' Thesis}

Analysis of previous Assembly elections has implied a partial fit with second-order electoral theory. Overall, the idea that second-order theory supplies a limited explanation of Assembly elections is supported by analysis of the 2011 contest. In particular, turnout in Wales in 2011 (regional vote) was approximately 24\% below that in Welsh constituencies at the 2010 UK General Election.

Similarly, public awareness and engagement was much lower, for example the campaign was partly eclipsed by major news stories like the Royal Wedding, the death of Osama Bin Laden and the UK-wide referendum on the Alternative Vote.

However, concerning other elements of the second-order model, the 2011 elections implied a much weaker fit. For example, the smaller parties did quite badly, the election strengthening the four-party hegemony in Wales, specifically Labour re-gained Blaenau Gwent, the BNP vote in North Wales collapsed, while UKIP and Greens also failed to win list AMs. The 2011 contest, in terms of the Conservative gains, also challenged second-order thesis assumptions that governing parties at the first-order level lose due to mid-term unpopularity at that level.

\section{Assembly Profile: Gender and Ethnicity}

The first two Assemblies had been lauded for impressive levels of representation of women. The first Assembly had $24(40 \%)$ female and $36(60 \%)$ male AMs. The second elections produced exactly equal numbers of men anc women and a majority of women AMs after Trish Law's 2006 by-election victory. However, rescinding affirmative action in particular led to a decline in the fourth contest. Overall, 25 women were elected $(42 \%)$, three fewer than in 2007, and five fewer than in 2003 after John Dixon's replacement Eluned Parrott. However, the Assembly returned a higher proportion of women than elsewhere in the British Isles.

Table 2: Women elected at most recent UK devolved and general elections 


\begin{tabular}{|l|c|c|c|c|}
\hline & Election Date & $\begin{array}{l}\text { Women } \\
\text { Elected }\end{array}$ & $\begin{array}{l}\text { Total } \\
\text { Elected }\end{array}$ & Women\% \\
\hline UK Parliament & May 2010 & 143 & 650 & 22.0 \\
\hline Scottish Parliament & May 2011 & 45 & 129 & 34.9 \\
\hline $\begin{array}{l}\text { National Assembly for } \\
\text { Wales }\end{array}$ & May 2011 & 25 & 60 & 41.7 \\
\hline $\begin{array}{l}\text { Northern Ireland } \\
\text { Assembly }\end{array}$ & May 2011 & 20 & 108 & 18.5 \\
\hline Dail (Ireland) & Feb 2011 & 25 & 166 & 15.1 \\
\hline
\end{tabular}

There had only been one AM classed as of black or minority ethnic origin (BME) elected in the first three Assemblies-Mohammed Ashgar, initially a Plaid and later a Conservative AM. In 2011, he was joined by the Labour AM Vaughan Gething, an outcome which meant that at 3.3\% BME representation exceeded the $2.1 \%$ of the population listed in the 2001 census.

\section{Proportionality}

The proportionality of electoral systems can be measured through calculating DV scores on the basis of a comparison of the percentage of seats won and the percentage of the votes for each party (here, regional list votes), or each least each main party. Lower scores indicate greater proportionality. In 2011, this calculation revealed an outcome more proportional than the 2007 result due mainly to movements in the Plaid and Liberal Democrat shares. In summary, the 2011 outcome had a DV score of 14.7 compared with 17.7 for the 2007 result.

Note: this piece is a summary of a piece which appeared in Parliamentary Affairs which was co-authored by Michael Cole and Laura McAllister. It represents the views of the author, and not those of Democratic Audit or the LSE. Please read our comments policy before posting. The shortened URL for this post is: http://buff.Iy/1IVR4JA

Michael Cole received his BSc in Politics from the University of Southampton in 1985. He stayed at Soutahmpton for his M.Phil thesis on the accountability of quangos, which he received in 1991. He also has a MSc in information science from City University (1990) and a $\mathrm{PhD}$ on local government modernisation from the University of Plymouth (2008). He has held full-time research appointments at the universities of Glamorgan, Northumbria, Exeter and Plymouth; and undertaken consultancy projects for several public sector organisations. 